\title{
Invasion Pathways of Karnal Bunt of Wheat into the United States
}

\author{
David Marshall, USDA/ARS, Plant Science Research Unit, Department of Plant Pathology, North Carolina State \\ University, Raleigh 27695-7616; Timothy T. Work, Department of Renewable Resources, University of Alberta, \\ Alberta T6G-2H1, Canada; and Joseph F. Cavey, USDA/APHIS/PPQ, 4700 River Road, Unit 133, Riverdale, MD \\ 20737
}

\begin{abstract}
Marshall, D., Work, T. T., and Cavey, J. F. 2003. Invasion pathways of Karnal bunt of wheat into the United States. Plant Dis. 87:999-1003.

Karnal bunt of wheat (caused by Tilletia indica) was first detected in the United States in Arizona in 1996. The seed lots of infected, spring-habit, durum wheat associated with the initial detection were traced to planted fields in California, Arizona, New Mexico, and Texas. However, in the summer of 1997, the disease appeared in unrelated, winter-habit, bread wheat located over $700 \mathrm{~km}$ from the nearest potentially contaminated wheat from 1996 (and destroyed prior to reinfection). Here, we examined potential invasion pathways of the fungus associated with the movement of wheat into the United States. We analyzed the USDA/APHIS Port Information Network (PIN) database from 1984 through 2000 to determine likely pathways of introduction based on where, when, and how the disease was intercepted coming into the United States. All interceptions were made on wheat transported from Mexico, with the majority (98.8\%) being intercepted at land border crossings. Karnal bunt was not intercepted from any other country over the 17-year period analyzed. Most interceptions were on wheat found in automobiles, trucks, and railway cars. The majority of interceptions were made at Laredo, Brownsville, Eagle Pass, and El Paso, TX, and Nogales, AZ. Karnal bunt was intercepted in all 17 years; however, interceptions peaked in 1986 and 1987. Averaged over all years, more interceptions $(19.2 \%)$ were made in the month of May than in any other month. Our results indicate that Karnal bunt has probably arrived in the United States on many occasions, at least since 1984. Because of the relatively unaggressive nature of the disease and its reliance on rather exacting weather conditions for infection, we surmised that it is possible this disease has a long period of latent survival between initial arrival and becoming a thriving, established disease.
\end{abstract}

Additional keywords: emerging disease, invasive species

In March of 1996, Karnal bunt was first discovered in the United States (12). The durum wheat seed lot in which the pathogen was found had been used to plant fields in Arizona, New Mexico, and Texas. The New Mexico and Texas fields were destroyed prior to pollination as a precaution to prevent infection and further spread of the disease (3). A federal quarantine was placed on the state of Arizona and affected areas of New Mexico, Texas, and later California, when the disease was found there. The areas under federal quarantine were amended as further information became available on the distribution of Karnal bunt. In the summer of 1997, a telio-

Corresponding author: David Marshall

E-mail: david_marshall@ncsu.edu

Accepted for publication 21 March 2003.

Publication no. D-2003-0519-05S

This article is in the public domain and not copyrightable. It may be freely reprinted with customary crediting of the source. The American Phytopathological Society, 2003. spore of Tilletia indica Mitra was found in a harvested grain sample of winter-habit, bread wheat from San Saba, TX, an area approximately $736 \mathrm{~km}$ east-northeast from the nearest destroyed field in 1996 (D. Marshall, unpublished data). Subsequent Karnal bunt surveillance activities did not detect the disease in any of the quarantined, regulated areas in 1998, 1999, and 2000 (National Agricultural Pest Information System, unpublished data). During the harvest of 2001, Karnal bunt was found again in harvested wheat grain near San Saba, TX, and was also found in grain produced from a four-county area surrounding Olney, TX (OLN), approximately $241 \mathrm{~km}$ north of San Saba (SSB) (Fig. 1).

The discovery of Karnal bunt in the southwestern United States from 1996 to 2001 led to questions concerning the introduction of the pathogen. Prior to its detection in the United States in 1996, Karnal bunt had been reported to occur in Afghanistan, India, Iran, Iraq, Lebanon, Mexico, Nepal, and Pakistan $(3,6)$. The disease was reported to occur in South Africa in 2000 (5). Since the discovery of the dis- ease in Mexico in 1972, Karnal bunt had been internally regulated by the Mexican government, and its dispersal was limited to the northwest portion of the country, in the states of Sonora and Sinaloa (4).

The arrival and subsequent establishment and spread of nonindigenous pathogens, insects, plants, and other organisms can result in severe economic loss of crops (either directly or through trade barriers) and can pose a significant ecological risk to native habitats and biodiversity (10). Regardless of the type of organism, successful invaders must negotiate a sequence of events that includes arriving, surviving, and thriving in a new environment (8). In practice, stemming the spread of invasive species depends on disrupting any part of this invasion sequence. Inspection and exclusion of pathogens at borders and other ports of entry is the primary means of limiting their arrival and entry into the United States (11). Limiting the survival of a pathogen after successful entry is the primary goal of regulatory activities such as eradication and quarantine. In the United States, the exclusion, eradication, and quarantine of plant pathogens is the responsibility of the USDA Animal and Plant Health Inspection Service (APHIS).

Natural pathways of introduction of nonindigenous plant pathogens are more common than those for other invasive species due to the ability of some pathogens to disseminate via air movement (8). However, immigration of nonindigenous species by natural pathways is minor compared with human-mediated dispersal. The growth of international trade and travel has increased the likelihood of immigration of nonindigenous, invasive species into the United States. Identification of pathways of introduction of nonindigenous species will aid in efforts to curtail their entry into the United States. We hypothesized that perhaps the best source of information presently available to identify likely pathways of invasion is data of plant pathogens intercepted at U.S. ports of entry. Thus, the purpose of this study was to analyze existing data in the APHIS Port Information Network (PIN) database in order to identify likely pathways of introduction of Karnal bunt into the United States by means other than natural air movement. 


\section{MATERIALS AND METHODS}

The USDA-APHIS Plant Protection and Quarantine (PPQ) division uses PPQ Form 309A to record information pertaining to nonindigenous organisms intercepted from materials and commodities of foreign origin. Information from this form is entered into the PIN database for each shipment of plants, plant parts, plant products, or other articles received from a single source that is found to have a prohibited plant pest or noxious weed. For each interception within the PIN database, the data recorded included port of entry (including specified location and the means of transportation arriving at the port), interception date, the identity of the pest, and a detailed description of where the pest was found during the inspection (for example baggage, mail, cargo, etc.), the commodity or host material associated with the pest, the country of origin, and the U.S. state of destination of the inspected items.

We converted the PIN database from its ASCII-based format into a relational database format using MSAccess in order to better analyze and query the data. Interception data from 1984 through 2000 were analyzed for this study. Interception data were tallied, averaged, and collated according to the parameter of interest, including port of entry, month, and year. Interceptions by year and by month were analyzed by one-way ANOVA $(P<0.05)$, and means were separated by LSD at the 5\% level of probability (Statistix7, Analytical Software, Tallahassee, FL).

\section{RESULTS}

Between 1984 and 2000, T. indica Mitra (=Neovossia indica (Mitra) Mundk.) was intercepted at U.S. borders 995 times. Of the 995 interceptions, $925(92.9 \%)$ were associated with wheat seed. The remaining 70 interceptions were omitted from further analysis because host material was not specified in the PIN database.

Interception sites. Of the interceptions where host material was specified, $T$. indica was intercepted almost exclusively (98.8\% or 914 of 925 interceptions) at 13 land border crossings between the United States and Mexico (Fig. 1). The greatest percentage of interceptions was made at Laredo, TX (43.8\%), with sizeable percentages of interceptions at Nogales, AZ (15.6\%), Brownsville, TX (12.4\%), Eagle Pass, TX (11.7\%), and El Paso, TX (10.7\%) (Fig. 2)

Ten interceptions of $T$. indica were recorded at airports and one at the inspection station at Beltsville, MD. No interceptions of $T$. indica were reported from marine ports or preclearance inspection sites located outside the United States. The 10 airport interceptions could be traced to three at Dallas/Ft. Worth, TX (one in 1993, two in 1998); two at El Paso, TX (one each in 1986 and 1995); two at Nogales, AZ (one each in 1985 and 1986); and one each at Tucson, AZ in 1992; Brownsville, TX in 1992; and San Antonio, TX in 1998. All 10 of the airport interceptions originated in Mexico and were detected on wheat grains in passenger baggage. The one inspection station interception at Beltsville, MD in 1989 was in a mail parcel originating from Mexico.

Type of conveyance. Karnal bunt interceptions at the 13 border locations arrived via four types of conveyances (Table 1). Nearly $40 \%$ of $T$. indica interceptions were associated with baggage, typically bags of wheat seed carried in an individual automobile or truck. However, these interceptions may have also arrived as small amounts of wheat seed carried in individuals' belongings. Another approximately $40 \%$ of $T$. indica interceptions fell into the "miscellaneous" category, which typically represented loose wheat grains found in truck beds, automobile trunks, and empty railroad cars.

Approximately $20 \%$ of the $T$. indica interceptions at the border crossings were made in commercial cargo (Table 1). More interceptions were reported on general cargo, which refers to nonagricultural items not regulated by APHIS, than on permit cargo, which contains agricultural items that require a formal permit and/or are quarantined. The majority of intercep-

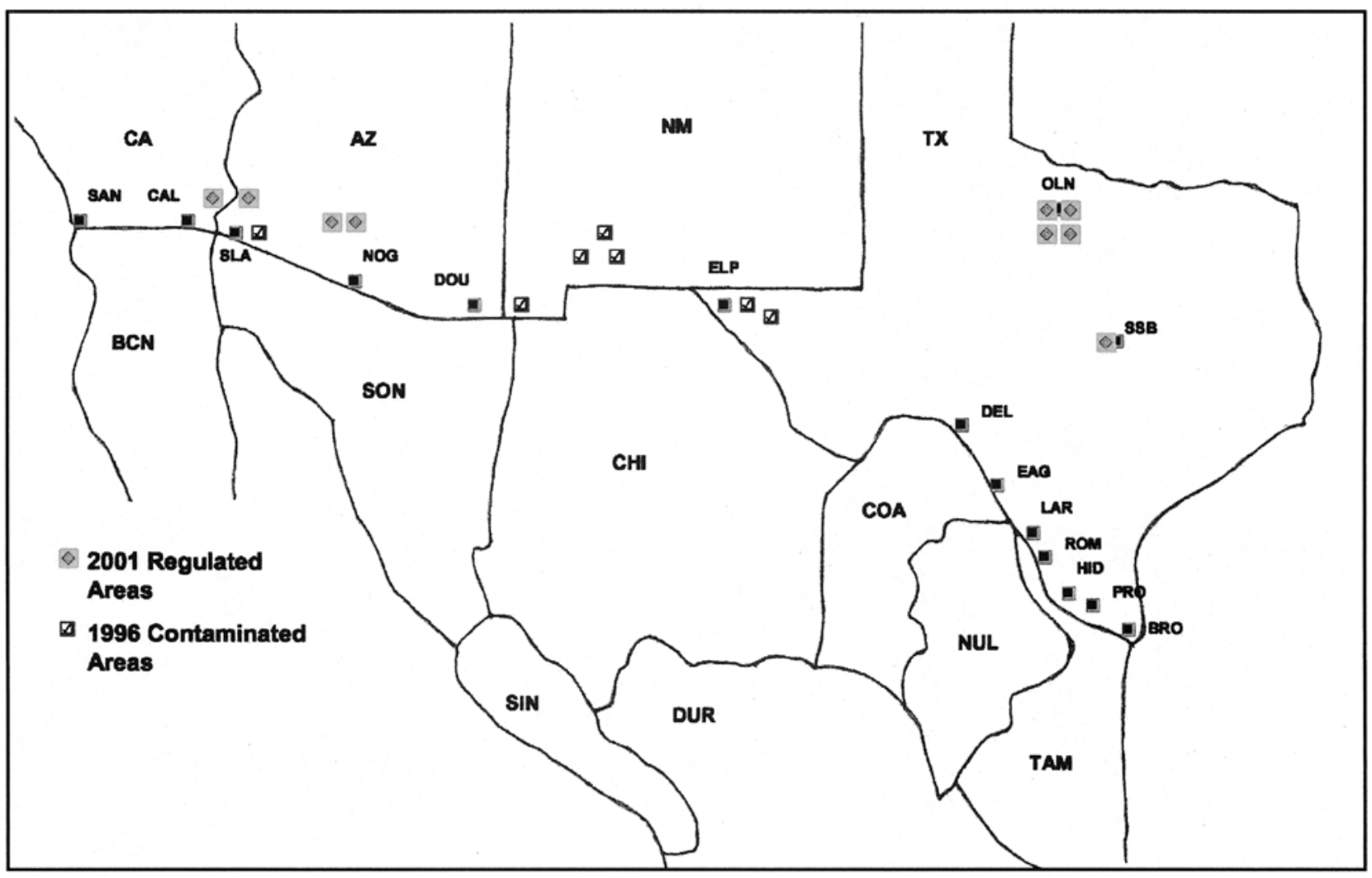

Fig. 1. Distribution of Karnal bunt of wheat in the United States in 1996 and 2001 and border cities where Karnal bunt was intercepted by USDA/APHIS between 1984 and 2000. Border crossings are DOU-Douglas, AZ; NOG-Nogales, AZ; SLA-San Luis, AZ; CAL-Calexico, CA; SAN-San Diego, CA; BRO-Brownsville, TX; DEL-Del Rio, TX; EAG-Eagle Pass, TX; ELP-El Paso, TX; HID-Hidalgo, TX; LAR-Laredo, TX; PRO-Progreso, TX; and ROMRoma, TX. Other city abbreviations are OLN-Olney, TX; and SSB-San Saba, TX. 
tions in general cargo were made in Laredo, TX, while the majority of permit cargo interceptions were made in Nogales, AZ.

Time of interceptions. Over the 17-year period of PIN data included in our analysis, $35.5 \%$ of all interceptions of $T$. indica were made during 1986 and 1987 (Fig. 3). These 2 years had significantly greater interceptions than all other years. Interceptions leveled off to an average of 31 per year from 1992 to 1996 , then spiked at 57 interceptions in 1997. Interceptions began and maintained an appreciable decline in 1998, 1999, and 2000 (Fig. 3). Averaged over years, a significantly greater number of interceptions were made during May (19.2\% of interceptions) than during any other month. The month with the fewest interceptions over years was July (4.0\%). However, the month with the peak number of interceptions in a given year varied somewhat, with May being the highest in 1985, 1986, and 1991-94; and January the highest in 1987, 1990, and 1996. The single highest number of interceptions of $T$. indica made in a month and year was 44 , made during May 1986 (Fig. 3).

\section{DISCUSSION}

Caution must be exercised when analyzing a historical database of this type. The PIN database contains over 850,000 entries of intercepted plants, pathogens, insects, mites, mollusks, and nematodes from all imported agricultural products and their conveyances, at all ports of entry into the United States beginning in 1984 and continuing through the present day. Each of the entries represents a single PPQ Form 309A, completed by an APHIS inspector or clerical staff, and subsequently entered into the database. Thus, human error in detection, identification, category classification, and data entry must be acknowledged as part of the database. However, by carefully analyzing the entries in the database, we omitted data entries that were clearly incorrect (for example, listing the pathogen as Tilletia indica but listing the plant part on which it was found as "bulbs"). We also did not include in our analysis those entries that were incomplete (for example, listing the host as wheat, the plant part as seed, but the pathogen as Tilletia sp.) or anomalous, as previously stated. Therefore, we believe the 925 interceptions of Karnal bunt of wheat from 1984 to 2000 represent conservative and reliable data.

Clearly, the pathway for introduction of Karnal bunt into the United States origi- nated in Mexico. All of the interceptions of Karnal bunt of wheat into the United States (including those data entries that were excluded from our analysis) originated in Mexico. The vast majority of these interceptions arrived at land borders in Texas, Arizona, and California from Mexico. Far fewer interceptions (10 out of 925) were made at airports; however, all of those could also be traced back to Mexico. Furthermore, Karnal bunt was never intercepted from any other country over the 17year period of this study, despite continued surveillance by APHIS.

Approximately $80 \%$ of the Karnal bunt interceptions were made from bags or loose grain found in automobiles, trucks, and railway cars. These modes of transport may represent a cryptic pathway for introduction of Karnal bunt, as such small quantities of grain that are not identified as

Table 1. Type of conveyance on or in which Karnal bunt of wheat was intercepted entering the United States at 13 land borders from 1984 to 2000

\begin{tabular}{lcccc}
\hline \multirow{2}{*}{$\begin{array}{l}\text { Location (total } \\
\text { interceptions) }\end{array}$} & Baggage & General cargo & Permit cargo & Miscellaneous \\
\cline { 2 - 5 } Douglas, AZ (2) & 2 & 0 & 0 & 0 \\
Nogales, AZ (143) & 42 & 7 & 54 & 40 \\
San Luis, AZ (1) & 0 & 1 & 0 & 0 \\
Calexico, CA (15) & 4 & 4 & 0 & 7 \\
San Diego, CA (4) & 4 & 0 & 0 & 0 \\
Brownsville, TX (113) & 18 & 5 & 0 & 90 \\
Del Rio, TX (7) & 7 & 0 & 0 & 0 \\
Eagle Pass, TX (107) & 80 & 5 & 0 & 22 \\
El Paso, TX (98) & 60 & 9 & 0 & 29 \\
Hidalgo, TX (8) & 2 & 0 & 1 & 5 \\
Laredo, TX (400) & 131 & 96 & 0 & 169 \\
Progreso, TX (1) & 0 & 0 & 0 & 0 \\
Roma, TX (15) & 15 & 0 & $59(6.5 \%)$ & $363(39.7 \%)$ \\
Total (\%) & $365(39.9 \%)$ & $127(13.9 \%)$ & &
\end{tabular}

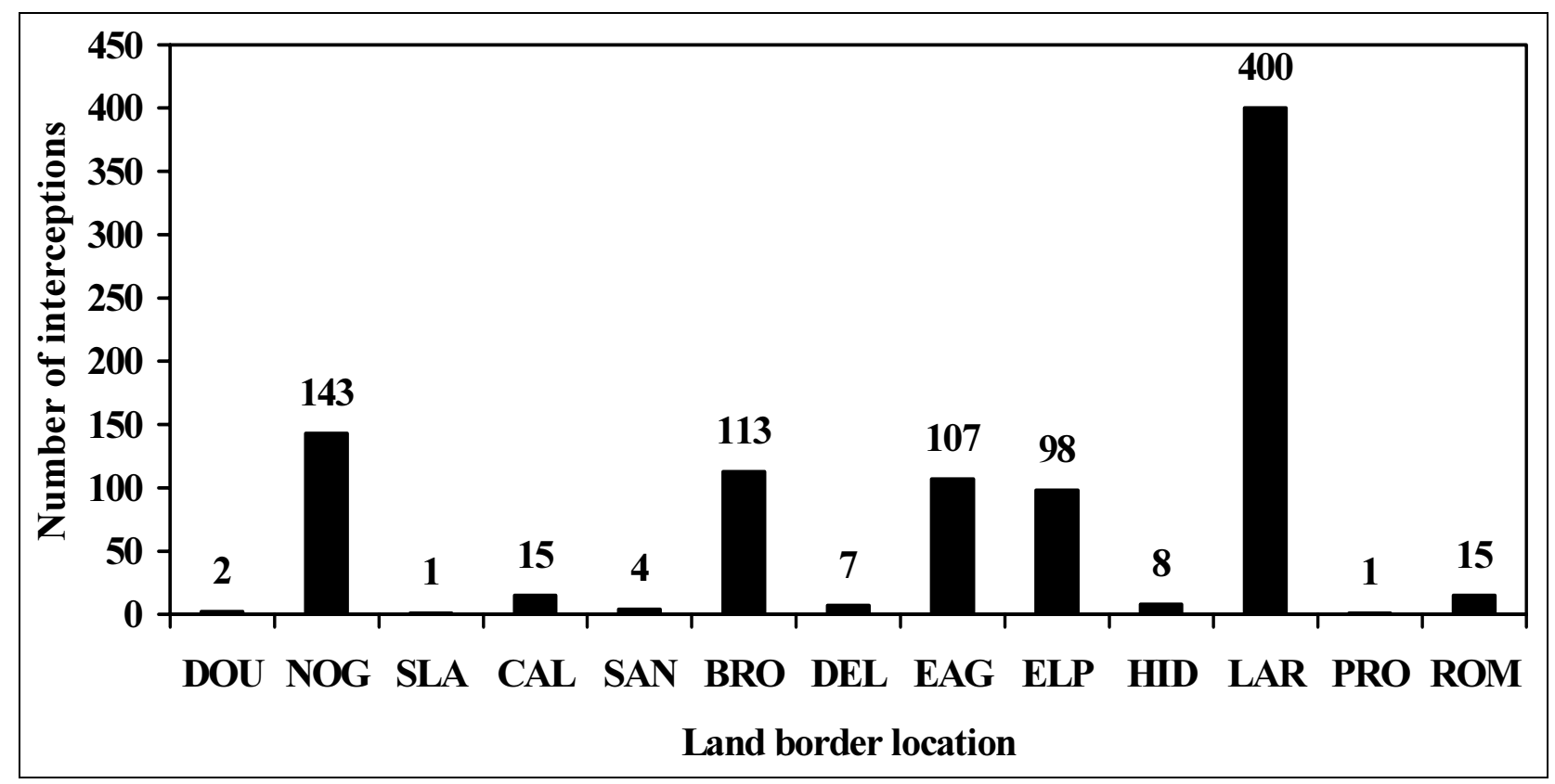

Fig. 2. Land border crossings and interceptions of Karnal bunt of wheat made in the United States from 1984 to 2000. Border crossings are DOU-Douglas, AZ; NOG-Nogales, AZ; SLA-San Luis, AZ; CAL-Calexico, CA; SAN-San Diego, CA; BRO-Brownsville, TX; DEL-Del Rio, TX; EAG-Eagle Pass, TX; ELP-El Paso, TX; HID-Hidalgo, TX; LAR-Laredo, TX; PRO-Progreso, TX; and ROM-Roma, TX. 
in other pathways through cargo manifests can not be targeted for inspection by APHIS. Likewise, loose grain infected with Karnal bunt within a transport vehicle has the potential to increase the opportunities for introduction of Karnal bunt if that transport vehicle is used to transport manifested cargo in the future without proper sanitation.

Surprisingly, commercial cargo represented just $20 \%$ of the interceptions, with most of those occurring in Laredo, TX, and Nogales, AZ. While the PIN database does give an indication of the relative size or amount (shipment size) of wheat seed associated with each interception, we found those data to be highly variable and inconsistent with regard to method of reporting, and therefore shipment size was not included in the analysis.

We found that $35.5 \%$ of the total number of Karnal bunt interceptions occurred in 1986 and 1987. In addition, most interceptions were made during May, although this varied somewhat from year to year. We conducted further analyses of the data set by single ports of entry in specific years with specific methods of conveyance and certain times of the year; however, the number of data points became few, and given the variable nature of the data, conclusions based on few data points were not made.
Of course, data on pathogen interceptions does not provide information on the number of times a pathogen is actually breaching our borders and subsequently attempting to survive in the United States. However, it is reasonable to think that an increase in interceptions is related to an increase in total volume of arrivals of Karnal bunt at our borders. In addition, only about $2 \%$ of baggage and cargo entering the United States is inspected by APHIS. Given the large amount of uninspected entries coupled with the PIN interception data, we can conclude that between 1984 and 2000, Karnal bunt of wheat most likely repeatedly entered the United States across our southern border with Mexico, mainly through Texas and typically associated with individual automobiles, trucks, and railway cars. Most of the introductions occurred in 1986 and 1987, but some have occurred each year, typically during the month of May. From 1998 to 2000, there was a decrease in the number of interceptions of Karnal bunt, despite heightened awareness resulting from the 1996 detection.

Because teliospores of $T$. indica associated with wheat seed have had ample opportunity to enter the United States from Mexico since at least 1984, it is possible that the outbreaks of the disease in central Texas (San Saba and Olney areas) were

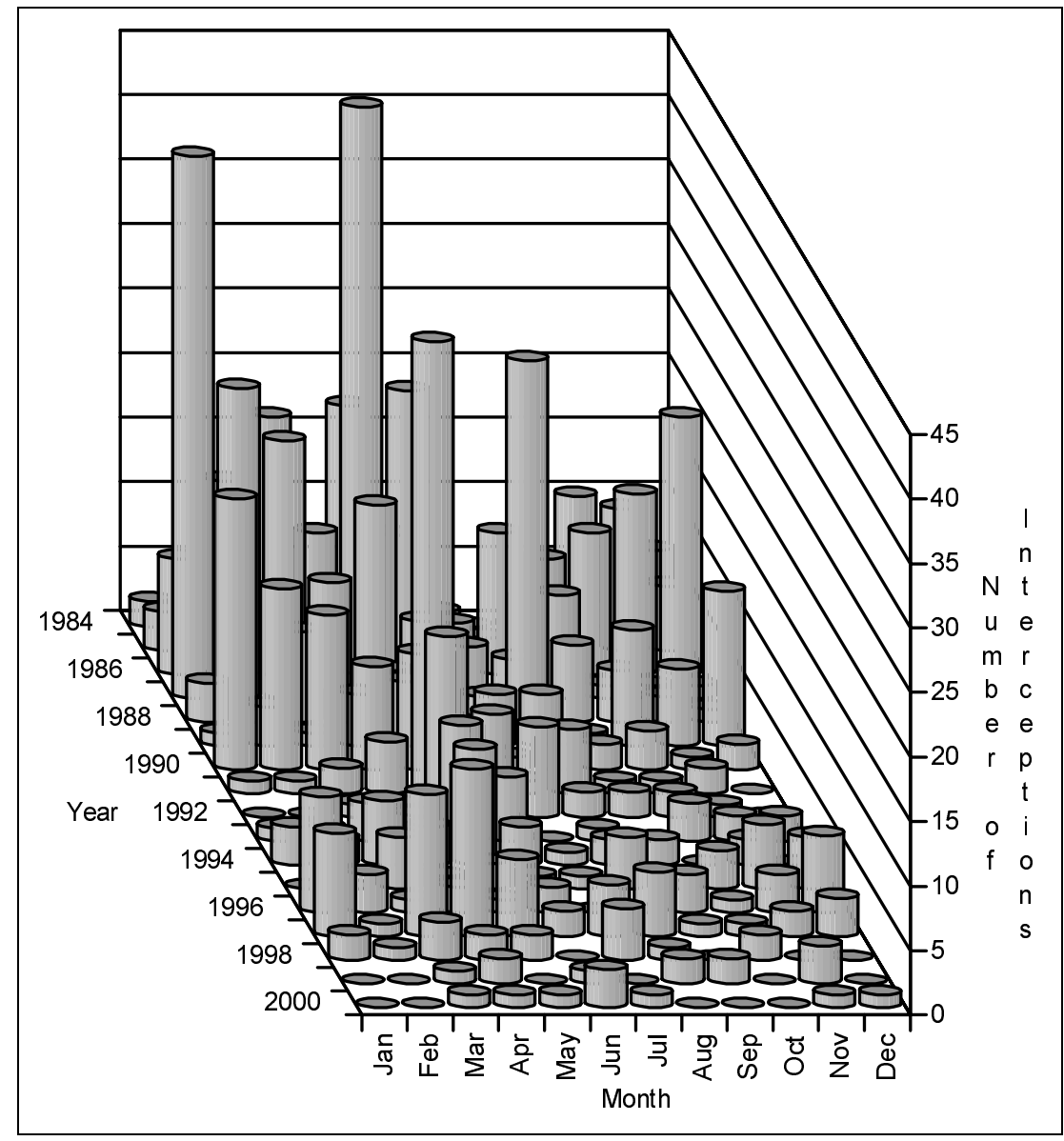

Fig. 3. Number of interceptions of Karnal bunt of wheat from 1984 to 2000 in the United States. associated with long-present $T$. indica populations. After several years of lowlevel, undetectable infections, the Karnal bunt-favorable weather in the San Saba area in the spring of 1997 may have caused sufficient infections to reach detectable levels in the harvested grain. Incidence and severity of Karnal bunt are highly reliant upon abundant rain, moderate temperatures, high relative humidity, and cloudiness during floral infection by teliospores (1). In addition, the disease typically infects only a small portion of a given wheat kernel, only a few kernels on a spike, and not all the spikes of a plant (thus leading to "partial bunt" as another common name for the disease) $(2,9)$. Therefore, it can be hypothesized that Karnal bunt of wheat and T. indica as an invasive species may have a relatively long lag-phase of survival following arrival of the pathogen and before the pathogen can thrive in an invaded agroecosystem. In addition, if the arriving populations are too small, they may be subject to the destabilizing Allee effect, resulting in reduced population levels (7). Aside from the purpose of this study, the possibility also exists for long-distance dissemination of teliospores and sporidia via wind from areas of infection in northwest Mexico to areas in the southwestern United States. Nevertheless, this study has clearly revealed the high probability of repeated introductions of Karnal bunt into the United States from Mexico dating back to 1984 .

\section{ACKNOWLEDGMENTS}

This research was sponsored in part by the National Center for Ecological Analysis and Synthesis, Santa Barbara, CA. We thank Deborah McCullough (Michigan State University), Sue Tolin (Virginia Polytechnic Institute), Sarah Reichard (University of Washington), Andrew Liebhold (USDA Forest Service), and Ron Komsa (USDA/APHIS/PPQ) for their helpful suggestions and reviews of this paper.

\section{LITERATURE CITED}

1. Aujla, S. S., Sharma, Y. R., Chand, K., and Sawney, S. A. 1977. Influence of weather factors on the incidence and epidemiology of Karnal bunt disease of wheat in the Punjab. Indian J. Ecol. 4:71-74.

2. Bedi, S. K. S., Sikka, M. R., and Mundkur, B. B. 1949. Transmission of wheat bunt due to Neovossia indica (Mitra) Mundkur. Indian Phytopathol. 2:20-26.

3. Bonde, M. R., Peterson, G. L., Schaad, N. W., and Smilanick, J. L. 1997. Karnal bunt of wheat. Plant Dis. 81:1370-1377.

4. Brennan, J. P., Warham, E. J., Byerlee, D., and Hernandez-Estrada, J. 1992. Evaluating the economic impact of quality reducing, seedborne diseases: Lessons from Karnal bunt of wheat. Agric. Econ. 6:345-352.

5. Crous, P. W., Van Jaarsveld, A. B., Castlebury, L. A., Carris, L. M., Frederick, R. D., and Pretorius, Z. A. 2001. Karnal bunt of wheat newly reported from the African continent. Plant Dis. 85:561.

6. Fuentes-Davila, G. 1996. Karnal bunt. Pages 26-32 in: Bunt and Smut Diseases of Wheat: Concepts and Methods of Disease Management. R. D. Wilcoxson and E. E. Saari, eds. CIMMYT, Mexico, D.F. 
7. Garrett, K. A., and Bowden, R. L. 2002. An Allee effect reduces the invasive potential of Tilletia indica. Phytopathology 92:1152-1159.

8. Mack, R. N., ed. 2002. Predicting Invasions of Nonindigenous Plants and Plant Pests. National Academy Press, Washington, DC.

9. Mitra, M. 1935. Stinking smut (bunt) of wheat with a special reference to Tilletia in- dica Mitra. Indian J. Agric. Sci. 5:1-24.

10. Pimentel, D., McNair, S., Janecka, J., Wightman, J., Simmonds, C., O'Connell, C., Wong, E., Russel, L., Zern, J., Aquino, T., and Tsomondo, T. 2001. Economic and environmental threats of alien plant, animal, and microbe invasions. Agric. Econ. Environ. 84:120.
11. U.S. Congress, Office of Technology Assessment. 1993. Harmful Non-Indigenous Species in the United States. U.S. Government Printing Office, Washington, DC.

12. Ykema, R. E., Floyd, J. P., Palm, M. E., and Peterson, G. L. 1996. First report of Karnal bunt of wheat in the United States. Plant Dis. 80:1207. 